\title{
IN VITRO PROPAGATION OF 'GISELA 5' ROOTSTOCK AS AFFECTED BY MINERAL COMPOSITION OF MEDIA AND PLANT GROWTH REGULATORS
}

\author{
Maliheh FALLAHPOUR ${ }^{1}$, Seied Mehdi MIRI ${ }^{1 *}$, Naser BOUZARI ${ }^{2}$ \\ ${ }^{1}$ Department of Horticulture, Karaj Branch, Islamic Azad University, Karaj, Iran \\ ${ }^{2}$ Department of Horticulture Research, Seed and Plant Improvement Research Institute, Karaj, Iran
}

Received: April, 2015; Accepted: June, 2015

\begin{abstract}
The purpose of the presented study was to determine the best mineral composition of media and plant growth regulators in the micropropagation of the 'Gisela 5' (Prunus cerasus $\times$ P. canescens) dwarf sweet cherry rootstock. Nodal explants from young healthy shoots were excised and cultured on Murashige and Skoog medium without growth regulators. In vitro raised shoot tips were transferred to three culture media including Murashige and Skoog (MS), Driver and Kuniyuki (DKW) and Lloyd and McCown (WPM) containing benzyl adenine (BA) $\left(0.5,1\right.$ or $\left.2 \mathrm{mg}^{-1^{-1}}\right)$ in combination with kinetin (Kin) at 0 or $0.5 \mathrm{mg} \cdot \mathrm{l}^{-1}$. WPM and DKW media were proving to be the most effective, resulting in a higher percentage of shoot multiplication and shoot number as compared to MS. BA in concentration $2 \mathrm{mg} \cdot \mathrm{l}^{-1}$ resulted in the highest number of microshoots per explant (3.1). For rooting, $0,0.5,1$ or $2 \mathrm{mg} \cdot 1^{-1}$ indole-3-butyric acid (IBA) on MS, DKW and WPM media were tested. WPM medium containing $2 \mathrm{mg} \cdot \mathrm{l}^{-1}$ IBA was most effective for rooting (93.7\%) in comparison to MS (53.1\%) and DKW (14.0\%).Rooted plantlets were successfully hardened and established in pots.
\end{abstract}

Key words: 'Gisela 5' rootstock, media, proliferation, rooting

\section{INTRODUCTION}

Nowadays, sweet cherry dwarf rootstocks are used for intensive orchards production (Drkenda et al. 2012). Dwarfing and semi-dwarfing rootstocks help gardeners to increase efficiency and fruit quality compared to standard rootstocks. 'Gisela 5' is a dwarfing rootstock for sweet cherry that was developed from the cross between Prunus cerasus 'Schattenmorelle' $\times P$. canescens at the University of Giessen (Long \& Kaiser 2010). 'Gisela 5' is known to reduce vigor by up to 50 percent or more compared to 'Mazzard' seedlings (Long 2003). Furthermore, this rootstock accelerated growth, flowering and fruiting (Erwin \& Ribeiro 1996; Long \& Kaiser 2010; Šiško 2011; Zimmermann 1994).
The 'Gisela 5' sweet cherry rootstock is propagated with greenwood, soft or hardwood cuttings (Exadaktylou et al. 2009), but also micropropagation has been reported (Ružić et al. 2000; Nacheva \& Gercheva 2009; Bošnjak et al. 2012; Clapa et al. 2013; Šiško 2011. An efficiency in tissue culture propagation is strongly influenced by a mineral composition of culture medium and its interaction with other medium compounds, as water quality, sugars, growth regulators, vitamins, etc. (Pierik 1997). To increase the effectivity of 'Gisela 5' micropropagation we investigated three different media and plant growth regulators on shoot proliferation and rooting of the 'Gisela 5' rootstock. 


\section{MATERIALS AND METHODS}

The explants were taken from actively growing shoots of 3-year-old 'Gisela 5' plants (Prunus cerasus $\times P$. canescens) grown in the experimental field of Seed and Plant Improvement Research Institute, Karaj, Iran, in September 2014.

Shoots were cut in 10 to $12 \mathrm{~cm}$ length segments, leaves were trimmed off and segments were washed under running water for 2 hours. Then shoots were presterilised by immersion in $70 \%(\mathrm{v} / \mathrm{v})$ ethanol for 60 seconds followed by a rinse three times with sterile distilled water and were exposed to $2.5 \%(\mathrm{v} / \mathrm{v})$ sodium hypochlorite to which 23 drops of Tween-20 were added for 15 minutes. After that, the explants were washed three times with sterile distilled water. One-bud segments 1.5$2 \mathrm{~cm}$ long were placed individually in vessels containing $10 \mathrm{ml}$ of MS medium without plant growth regulators. After four weeks, explants were subcultured to $250 \mathrm{~cm}^{3}$ jars containing $40-50 \mathrm{ml}$ of fresh medium. After three subcultures at 4-week intervals, the microshoots were used in experiments.

Three media were evaluated: Murashige and Skoog - MS (1962), Driver and Kuniyuki - DKW (1984) and Lloyd and McCown - WPM (1980). Media contained $0.5,1$ or $2 \mathrm{mg} \cdot 1^{-1}$ benzyladenine (BA) in combination with 0 or $0.5 \mathrm{mg} \cdot \mathrm{l}^{-1}$ kinetin (Kin). All media were supplemented with $3 \%(\mathrm{w} / \mathrm{v})$ sucrose and $7 \mathrm{~g} \cdot \mathrm{l}^{-1}$ agar. The $\mathrm{pH}$ of media was adjusted to $5.6-5.8$ with $1 \mathrm{~N} \mathrm{NaOH} / \mathrm{HCl}$ prior to autoclaving at $1.05 \mathrm{~kg} \cdot \mathrm{cm}^{-2}, 121^{\circ} \mathrm{C}$ for $20 \mathrm{~min}$. Cultures were maintained at $23 \pm 1^{\circ} \mathrm{C}$ air temperature in a culture room with a $16 / 8 \mathrm{~h}$ photoperiod under an illumination of 2400 lux provided by cool-white fluorescent light, and with $45 \%$ relative humidity. Percent of explants proliferating as well as number $(>5 \mathrm{~mm})$ and length of axillary shoots were recorded after 45 days of culture.

Shoots tips (20 to $30 \mathrm{~mm}$ long) formed on multiplication medium were transferred to MS, DKW and WPM media supplemented with $0,0.5,1$ or $2 \mathrm{mg} \cdot 1^{-1}$ indole-3-butyric acid (IBA). After 45 days, rooting percentage, the number and length of the roots per explant were recorded.

Plantlets with properly developed roots were gently taken out from the culture flasks and washed thoroughly under running tap water to remove the remaining agar. They were transferred to lidded vessels containing peat moss, coir and perlite $(2: 2: 1$ $\mathrm{v} / \mathrm{v}$ ) treated with $0.2 \mathrm{~g} \cdot \mathrm{l}^{-1}$ Mancozeb fungicide (Aria, Iran) in water. The top of the pots was covered with transparent plastic and grown in a shaded greenhouse at $23 \pm 1{ }^{\circ} \mathrm{C}$ and sprayed with water once a day to maintain the humidity. Three weeks later, the plastic covers were removed and the plantlets were watered two times a day. Following adaptation the plants were transferred into bigger pots containing the same substrate, and shifted to shade house with less humidity and indirect sunlight.

The experiments were set up as a factorial in a completely randomized design and repeated three times. Each treatment included three replicates (jars), with two explants in each in proliferation phase and four replicates (with four explants in each) in rooting phase. Analysis of variance (ANOVA) and Pearson's correlation coefficient were performed using SPSS.16 software and significant differences $(p<0.05)$ among the means were determined by Duncan's multiple range test.

\section{RESULTS AND DISCUSSION}

In this study, a contamination percentage was $4 \%$. Visibly noncontaminated explants started bud break and shoot growth within 5-7 days.

Forty-five days of incubation of shoot tip explants in MS, DKW and WPM media supplemented with $0.5,1$ or $2 \mathrm{mg} \cdot 1^{-1} \mathrm{BA}$ in combination with 0 or $0.5 \mathrm{mg} \cdot \mathrm{l}^{-1} \mathrm{Kin}$ resulted in the formation and growth of axillary shoots. The influence of media mineral composition was significant (Table 1). On DKW and WPM media, maximum shoot multiplication percentage was recorded in comparison to MS (69.4\%) (Table 2).

Also, on DKW and WPM medium shoot number was significantly higher (2.4 and 3.3 per explant respectively) than on MS medium (1.6 per explant) (Fig. 1. 1-3 and Table 2). There was no significant interaction between the culture media and plant growth regulators on shoot number (Table 1). The highest number of axillary shoots (3.1) was formed on the media containing $2 \mathrm{mg} \cdot \mathrm{l}^{-1} \mathrm{BA}$ (Table 3 ). The effect of Kin on shoot number was insignificant (Table 1). 


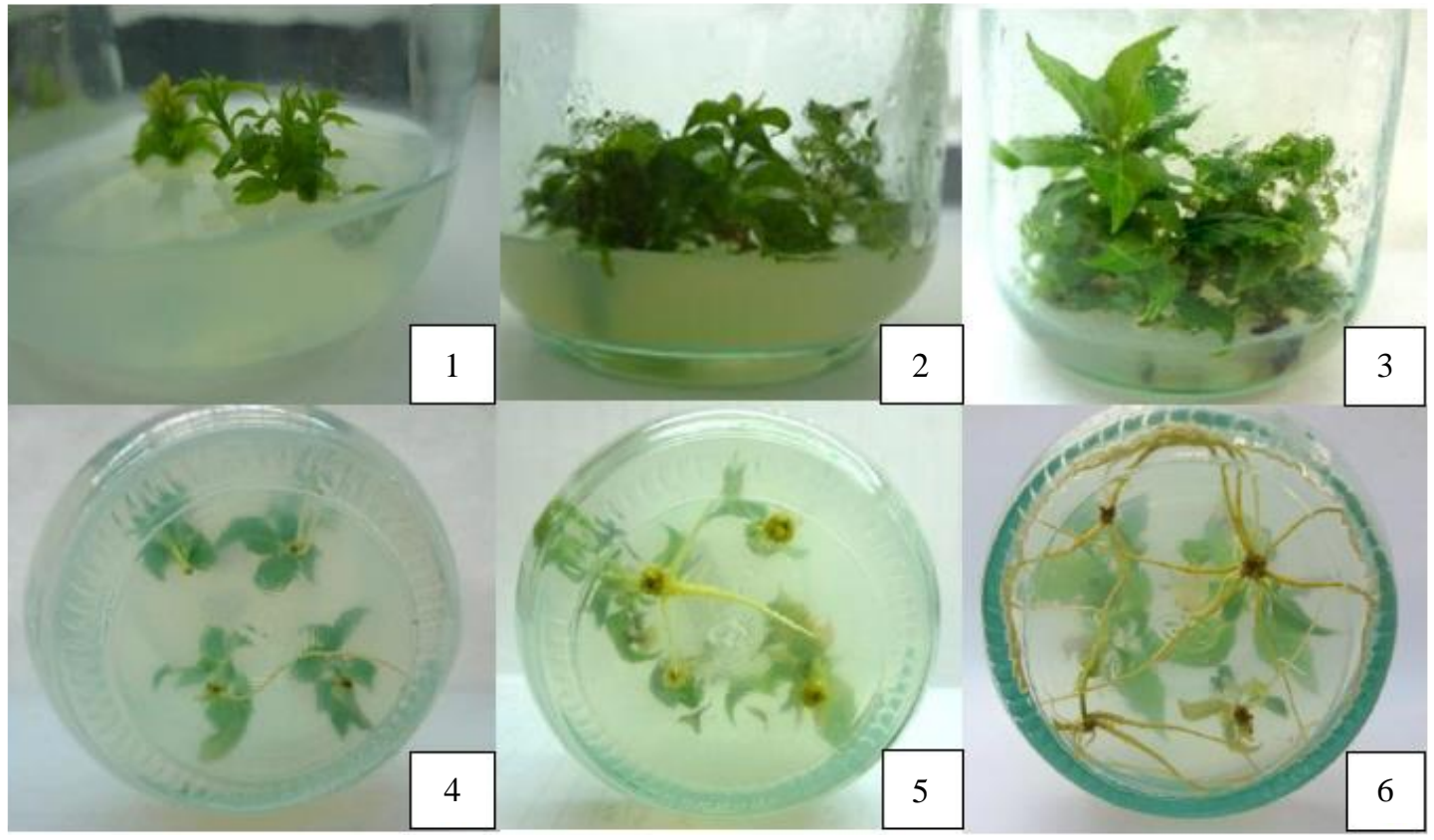

Fig. 1. The effects of media on proliferation and rooting of 'Gisela 5': proliferation stage: $1-\mathrm{MS}, 2-\mathrm{DKW}, 3-\mathrm{WPM}$; rooting stage: 4 - MS, 5 - DKW, $6-$ WPM

Table 1. ANOVA table of the effects of media and cytokinins on proliferation of 'Gisela 5'

\begin{tabular}{ccccc}
\hline & & \multicolumn{3}{c}{ Mean squares } \\
\cline { 3 - 4 } Effect & Df & $\begin{array}{c}\text { Percentage of prolifer- } \\
\text { ated shoots }\end{array}$ & Shoot no. & Shoot length \\
\hline Media & 2 & $5138.88^{*}$ & $12.51^{*}$ & $0.84^{*}$ \\
BA & 2 & $138.88^{\mathrm{ns}}$ & $6.24^{*}$ & $0.02^{\mathrm{ns}}$ \\
Kin & 1 & $0.00^{\mathrm{ns}}$ & $1.85^{\mathrm{ns}}$ & $0.62^{*}$ \\
Media $\times$ BA & 4 & $69.44^{\mathrm{ns}}$ & $0.49^{\mathrm{ns}}$ & $0.25^{*}$ \\
Media $\times$ Kin & 2 & $138.88^{\mathrm{ns}}$ & $0.15^{\mathrm{ns}}$ & $0.01^{\mathrm{ns}}$ \\
BA $\times$ Kin & 2 & $138.88^{\mathrm{ns}}$ & $3.13^{\mathrm{ns}}$ & $0.64^{*}$ \\
Media $\times$ BA $\times$ Kin & 4 & $69.44^{\mathrm{ns}}$ & $2.71^{\mathrm{ns}}$ & $0.45^{*}$ \\
Error & 36 & 324.074 & $1.05^{\circ}$ & 0.06 \\
CV $(\%)$ & - & 2.36 & 5.46 & 6.89 \\
\hline
\end{tabular}

ns and * insignificant and significant at $5 \%$ probability level, respectively.

Table 2. Effect of media on shoot multiplication percentage and shoot number of 'Gisela 5'

\begin{tabular}{cccc}
\hline Medium & $\begin{array}{c}\text { No. ex- } \\
\text { plants }\end{array}$ & $\begin{array}{c}\text { Shoot multipli- } \\
\text { cation }(\%)\end{array}$ & Shoot no. \\
\hline MS & 108 & $69.4 \pm 4.1 \mathrm{~b}$ & $1.6 \pm 0.2 \mathrm{~b}$ \\
DKW & 108 & $97.2 \pm 1.9 \mathrm{a}$ & $2.4 \pm 0.3 \mathrm{a}$ \\
WPM & 108 & $100.0 \pm 0.0 \mathrm{a}$ & $3.3 \pm 0.3 \mathrm{a}$ \\
\hline
\end{tabular}

Values in each column represent means \pm SE. Different letters within columns indicate significant differences according to the Duncan's multiple range test $(\mathrm{P}<0.05)$.
Table 3. Effect of BA on shoot number of 'Gisela 5'

\begin{tabular}{ccc}
\hline BA $\left(\mathrm{mg} \cdot \mathrm{l}^{-1}\right)$ & No. explants & Shoot no. \\
\hline 0.5 & 108 & $2.3 \pm 0.3 \mathrm{~b}$ \\
1 & 108 & $1.9 \pm 0.3 \mathrm{~b}$ \\
2 & 108 & $3.1 \pm 0.3 \mathrm{a}$ \\
\hline
\end{tabular}

Values in each column represent means \pm SE. Different letters within columns indicate significant differences according to the Duncan's multiple range test $(\mathrm{P}<0.05)$. 
The maximum average shoot length $(1.2 \mathrm{~cm})$ was recorded on DKW medium supplemented with $0.5 \mathrm{mg} \cdot \mathrm{l}^{-1} \mathrm{BA}$ and $0.5 \mathrm{mg} \cdot \mathrm{l}^{-1} \mathrm{Kin}$ (Table 4). Also, relatively high shoots were grown on the DKW medium $+2 \mathrm{mg} \cdot \mathrm{l}^{-1} \mathrm{BA}$ and WPM medium $+2 \mathrm{mg} \cdot \mathrm{l}^{-1}$ $\mathrm{BA}+0.5 \mathrm{mg} \cdot \mathrm{l}^{-1} \mathrm{Kin}$, where a mean shoot length of 0.95 and $0.86 \mathrm{~cm}$ was recorded, respectively.

The shoot multiplication percentage, the shoot length and the number of shoots per explant were positively correlated (Table 5).

Table 4. Effect of media and cytokinins on shoot length of 'Gisela 5'

\begin{tabular}{|c|c|c|c|c|}
\hline Medium & $\begin{array}{c}\text { BA } \\
\left(\mathrm{mg} \cdot \mathrm{l}^{-1}\right) \\
\end{array}$ & $\begin{array}{c}\text { Kin } \\
\left(\mathrm{mg} \cdot \mathrm{l}^{-1}\right) \\
\end{array}$ & $\begin{array}{l}\text { No. ex- } \\
\text { plants }\end{array}$ & $\begin{array}{l}\text { Shoot length } \\
(\mathrm{cm})\end{array}$ \\
\hline \multirow[t]{6}{*}{ MS } & 0.5 & 0 & 18 & $0.15 \pm 0.05 \mathrm{~g}$ \\
\hline & & 0.5 & 18 & $0.31 \pm 0.15 \mathrm{~d}-\mathrm{g}$ \\
\hline & 1 & 0 & 18 & $0.18 \pm 0.07 \mathrm{fg}$ \\
\hline & & 0.5 & 18 & $0.45 \pm 0.22 \mathrm{~d}-\mathrm{g}$ \\
\hline & 2 & 0 & 18 & $0.18 \pm 0.07 \mathrm{fg}$ \\
\hline & & 0.5 & 18 & $0.19 \pm 0.04 \mathrm{e}-\mathrm{g}$ \\
\hline \multirow[t]{6}{*}{ DKW } & 0.5 & 0 & 18 & $0.40 \pm 0.06 \mathrm{~d}-\mathrm{g}$ \\
\hline & & 0.5 & 18 & $1.21 \pm 0.27 \mathrm{a}$ \\
\hline & 1 & 0 & 18 & $0.55 \pm 0.05 \mathrm{c}-\mathrm{g}$ \\
\hline & & 0.5 & 18 & $0.66 \pm 0.10 \mathrm{~b}-\mathrm{d}$ \\
\hline & 2 & 0 & 18 & $0.95 \pm 0.12 \mathrm{ab}$ \\
\hline & & 0.5 & 18 & $0.56 \pm 0.04 \mathrm{c}-\mathrm{f}$ \\
\hline \multirow[t]{6}{*}{ WPM } & 0.5 & 0 & 18 & $0.31 \pm 0.07 \mathrm{~d}-\mathrm{g}$ \\
\hline & & 0.5 & 18 & $0.70 \pm 0.15 b-d$ \\
\hline & 1 & 0 & 18 & $0.54 \pm 0.12 \mathrm{c}-\mathrm{g}$ \\
\hline & & 0.5 & 18 & $0.42 \pm 0.05 \mathrm{~d}-\mathrm{g}$ \\
\hline & 2 & 0 & 18 & $0.59 \pm 0.05 \mathrm{~b}-\mathrm{e}$ \\
\hline & & 0.5 & 18 & $0.86 \pm 0.14 \mathrm{a}-\mathrm{c}$ \\
\hline
\end{tabular}

Values in each column represent means \pm SE. Different letters within columns indicate significant differences according to the Duncan's multiple range test $(\mathrm{P}<0.05)$.

Table 5. Correlation coefficient between shoot multiplication percentage, shoot number and shoot length

\begin{tabular}{ccc}
\hline & $\begin{array}{c}\text { Shoot multiplica- } \\
\text { tion }(\%)\end{array}$ & Shoot No. \\
\hline Shoot No. & $0.546^{* *}$ & \\
Shoot length & $0.554^{* *}$ & $0.695^{* *}$ \\
\hline
\end{tabular}

** significant at $1 \%$ probability level.
The mineral composition of the medium was reported as an important factor influencing in vitro propagation of 'Gisela 5' rootstock. Ružić et al. (2000) obtained a better growth and development on MS and MS $\times 2$ than on $1 / 2$ MS and $1 / 4$ MS. Šiško (2011) reported that the WPM medium showed the highest multiplication rate (4.2 shoots/explant) in 'Gisela 5' rootstock, whereas the MS medium showed the lowest one (3.0 shoots/explant). Bošnjak et al. (2012) propagated successfully 'Gisela 5' on Quorin and Lepoivre - QL medium (1977). DKW medium containing $0.5 \mathrm{mg} \cdot \mathrm{l}^{-1} \mathrm{BA}$ was used for Gisela slow growth storage (Lambardi et al. 2006). Dorić et al. (2014) used this medium to the in vitro propagation of different cherry rootstocks, including 'Gisela 6'. Although MS medium is still most widely used, it is often replaced by media of lower salt concentration, especially those with lower nitrogen content, including the content of ammonium nitrate which is $1650 \mathrm{mg} \cdot \mathrm{l}^{-1} \mathrm{in}$ MS medium and 1416 and $400 \mathrm{mg} \cdot 1^{-1}$ in DKW and WPM, respectively. Most plants prefer nitrate to ammonium, and ammonium has been proved to be harmful for explants (Pierik 1997; Mansseri-Lamrioui et al. 2011), because the excess of nitrate can be stored in vacuoles and high ammonium can be toxic (Glass et al. 2002). On the other hand, DKW and WPM media have a higher calcium concentration compared to MS medium. Calcium has an important role in cell signaling (Reddy 2001) acting as a secondary messenger together with signal transduction proteins and also it maintains the integrity of the plasmalemma by connecting various proteins and lipids on membrane surfaces (Hirschi 2004). The integrity of the plasmalemma leads to a greater turgor pressure (higher water content) and nutrient retention in cells (Fenn \& Feagley 1999). Furthermore, Ca may have a direct effect on cell and organ growth. It is involved in cell elongation and cell division, influences cellular $\mathrm{pH}$, and also acts as a regulatory ion in the source-sink translocation of carbohydrates through its effects in cells and cell walls (Hirschi 2004). Overall, the enhanced growth of 'Gisela 5' in DKW and WPM media can be the result of a better nutritional status as discussed previously. Bošnjak et al. (2012) used Quoirin and Lepoivre 
(QL) nutrient medium instead of MS for the in vitro proliferation of the 'Gisela 5' cherry rootstock. They stated that full-strength MS is too high in ammonium $(20.6 \mathrm{mM})$ and nitrate ions ( $39.4 \mathrm{mM})$, while QL is a low ammonium medium $(5 \mathrm{mM})$. In addition, QL uses calcium nitrate as a nitrogen source, therefore, it has a higher calcium concentration.

BA proved to be useful in the shoot multiplication of 'Gisela 5'. In contrast to BA-enriched medium alone, we did not find a significant response in the media containing Kin. This is in agreement with the results of Šiško (2011) who found that shoot number and shoot length of 'Gisela 5' were greatest with $2 \mathrm{mg} \cdot \mathrm{l}^{-1}$ BAP. Augusto (2001) compared the effect of different cytokinins and observed that Kin produced fewer new shoots per explant in relation to BA. Ružić and Vujovic (2008) showed that Kin increased the shoot length of cherry cv. 'Lapins', but according to our results, Kin did not have a positive effect on the in vitro proliferation of 'Gisela 5'.

The best rooting was in WPM medium on which $93.7 \%$ of shoots were rooted, compared to $53.1 \%$ on MS and $14.0 \%$ on DKW (Fig. 1. 4-6 and Table 7). In addition, roots were most abundant 13.0 versus 7.6 and 1.8 in MS and DKW, respectively. Roots were also the longest on WPM me$\operatorname{dium}(5.5 \mathrm{~cm})$ while on MS and DKW were 0.9 and $0.6 \mathrm{~cm}$ long, respectively. The medium $\times$ IBA interaction was insignificant for rooting (Table 6). According to the results, the WPM medium with the lower mineral concentration (especially nitrogen) increased the in vitro rooting of 'Gisela 5'. The favorable effect of a diluted mineral solution on rooting can be explained by the reduction of nitrogen concentration (Driver \& Suttle 1987). Dimassi-
Theriou (1995) and Fotopoulos and Sotiropoulos (2005) reported that reducing the concentration of the MS minerals to half the normal value increased rooting percentage and stimulated the root elongation of the GF 677 (peach) and PR 204/84 (peach $\times$ almond) rootstocks, respectively. Also, the dry mass of roots of PR 204/84 grown on $1 / 2$ MS was significantly higher in comparison with MS at all IBA concentrations tested.

The rooting percentage of the shoots was increased in comparison to the control (IBA-free medium) (Table 8). Sarropoulou et al. (2013) stated that the best results for rooting percentage were obtained with $2 \mathrm{mg} \cdot \mathrm{l}^{-1} \mathrm{IBA}$ in 'Gisela 6' and CAB-6P rootstocks. Our study confirmed the above results. Increasing IBA concentration of three media types resulted in an increased root number and length. The number of roots per explant and root length were highest in the medium supplemented with $2 \mathrm{mg} \cdot \mathrm{l}^{-1}$ IBA (Table 8). Similar results were reported by Dorić et al. (2014) who obtained the maximum number of roots and roots length in 'SV1' selection ( $P$. fruticosa) at the highest IBA concentration.

There is a significant positive correlation between rooting percentage and root number per explant $(r=0.77, p<0.05)$ as well as between rooting percentage and root length $(\mathrm{r}=0.78, \mathrm{p}<0.05)(\mathrm{Ta}-$ ble 9). Also, statistically significant correlations were computed between root number and root length $(r=0.60, p<0.05)$. These results suggest that treatments increasing the percentage of rooting also increased rooting quality in terms of number and length of roots.

$93 \%$ of in vitro rooted shoots was able to acclimatize and grow in the greenhouse (Fig. 2).

Table 6. ANOVA table of the effects of media and IBA on rooting of 'Gisela 5'

\begin{tabular}{ccccc}
\hline \multirow{2}{*}{ Effect } & Df & \multicolumn{3}{c}{ Mean squares } \\
\cline { 3 - 5 } & & Rooting percentage & Root no. & Root length \\
\hline Media & 2 & $2540.65^{*}$ & $459.40^{*}$ & $120.51^{*}$ \\
IBA & 3 & $3936.63^{*}$ & $293.58^{*}$ & $5.85^{*}$ \\
Media $\times$ IBA & 4 & $681.42^{\mathrm{ns}}$ & $43.479^{\mathrm{ns}}$ & $0.40^{\mathrm{ns}}$ \\
Error & 36 & 542.51 & 34.49 & 0.76 \\
CV $(\%)$ & - & 7.98 & 11.26 & 10.38 \\
\hline
\end{tabular}

ns and $*$ - Insignificant and significant at $5 \%$ probability level, respectively. 
Table 7. Effect of media on rooting percentage, root number and root length of 'Gisela 5'

\begin{tabular}{ccccc}
\hline Medium & No. explants & Rooting $(\%)$ & Root no. & Root length $(\mathrm{cm})$ \\
\hline MS & 192 & $53.1 \pm 9.9 \mathrm{~b}$ & $7.7 \pm 2.6 \mathrm{~b}$ & $1.0 \pm 0.2 \mathrm{~b}$ \\
DKW & 192 & $14.1 \pm 5.1 \mathrm{c}$ & $1.9 \pm 0.7 \mathrm{c}$ & $0.6 \pm 0.2 \mathrm{~b}$ \\
WPM & 192 & $93.8 \pm 4.8 \mathrm{a}$ & $13.0 \pm 1.6 \mathrm{a}$ & $5.5 \pm 0.3 \mathrm{a}$ \\
\hline
\end{tabular}

Values in each column represent means \pm SE. Different letters within columns indicate significant differences according to the Duncan's multiple range test $(\mathrm{P}<0.05)$.

Table 8. Effect of IBA on rooting percentage, root number and root length of 'Gisela 5'

\begin{tabular}{ccccc}
\hline IBA $\left(\mathrm{mg} \cdot \mathrm{l}^{-1}\right)$ & No. explants & Rooting $(\%)$ & Root no. & Root length $(\mathrm{cm})$ \\
\hline 0 & 144 & $29.2 \pm 11.9 \mathrm{~b}$ & $2.8 \pm 1.3 \mathrm{~b}$ & $1.5 \pm 0.6 \mathrm{c}$ \\
0.5 & 144 & $56.3 \pm 13.5 \mathrm{a}$ & $6.2 \pm 1.6 \mathrm{~b}$ & $2.2 \pm 0.8 \mathrm{bc}$ \\
1 & 144 & $56.3 \pm 11.6 \mathrm{a}$ & $6.6 \pm 1.7 \mathrm{~b}$ & $2.6 \pm 0.7 \mathrm{ab}$ \\
2 & 144 & $73.0 \pm 10.4 \mathrm{a}$ & $14.5 \pm 3.5 \mathrm{a}$ & $3.1 \pm 0.8 \mathrm{a}$ \\
\hline
\end{tabular}

Values in each column represent means \pm SE. Different letters within columns indicate significant differences according to the Duncan's multiple range test $(\mathrm{P}<0.05)$.

Table 9. Correlation coefficient among rooting percentage, root number and root length

\begin{tabular}{ccc}
\hline & Rooting $(\%)$ & Root No. \\
\hline Root No. & $0.773^{* *}$ & \\
Root length & $0.782^{* *}$ & $0.601^{* *}$ \\
\hline
\end{tabular}

** significant at $1 \%$ probability level.

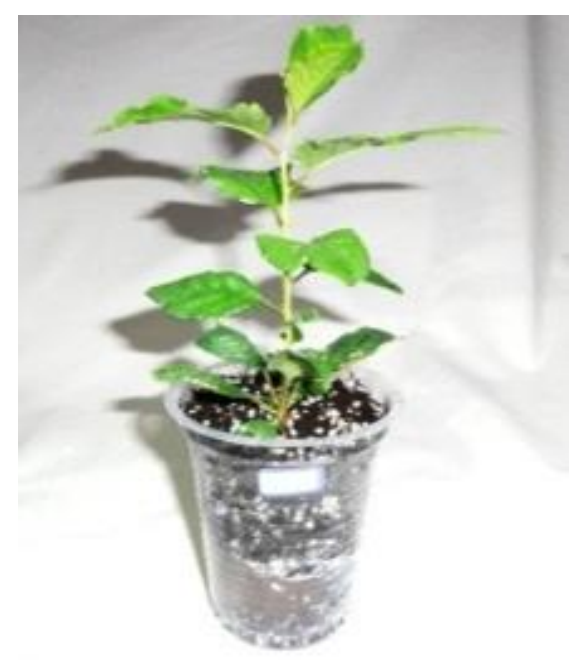

Fig. 2. Acclimatized 'Gisela 5' plant after 45 days

\section{CONCLUSION}

An in vitro protocol was developed to propagate 'Gisela 5' sweet cherry rootstock. DKW or WPM medium including $2 \mathrm{mg} \cdot \mathrm{l}^{-1} \mathrm{BA}$ was suitable for effective shoot proliferation and the WPM medium with $2 \mathrm{mg} \cdot \mathrm{l}^{-1}$ IBA was the best medium for rooting. Plantlets were successfully acclimatized and robust plants were achieved.

\section{REFERENCES}

Augusto C.S.S. 2001. Micropropagação de amoreirapreta cv. Brazos. Dissertação, Mestrado em Produção Vegetal, Universidade Federal do Paraná, Curitiba, Paraná, Brasil 30: 266-270.

Bošnjak A.M., Kereša S., Jerčić I.H., Barić M. 2012. The effect of cytokinin type and explant orientation on axillary shoot proliferation and in vitro rooting of 'Gisela 5' cherry rootstock. Journal: Food, Agriculture and Environment 10(3\&4): 616-620.

Clapa D., Fira A., Joshee N. 2013. An efficient ex vitro rooting and acclimatization method for horticultural plants using float hydroculture. HortScience 48(9): 1159-1167. 
Dimassi-Theriou K. 1995. In vitro rooting of rootstock GF 677 ( $P$. persica $\times P$. amygdalus $)$ as influenced by mineral concentration of the nutrient medium and type of culture-tube sealing material. Journal of Horticultural Science \& Biotechnology 70(1):105-108.

Dorić D., Ognjanov V., Ljubojević, M., Barać G., Dulić J., Pranjić A., Dugalić K. 2014. Rapid propagation of sweet and sour cherry rootstock. Notulae Botanicae Horti Agrobotanici Cluj-Napoca 42(2): 488-494. DOI: 10.15835/nbha.42.2.9671.

Driver J.A., Kuniyuki A.H. 1984. In vitro propagation of Paradox walnut Juglans hindsii $\times$ Juglans regia rootstock. HortScience 19: 507-509.

Driver J.A., Suttle G.R. 1987. Nursery handling of propagules. In: Bonga J.M. et al. (Eds.), Cell and tissue culture in forestry. Forestry Sciences, vol. 24-26, Dordrecht, Martinus Nijhoff Publishers, pp. 320335. DOI: 10.1007/978-94-009-4484-8_17.

Drkenda P., Spahić A., Spahić A., Begić-Akagić A. 2012. Testing of 'Gisela 5' and 'Santa Lucia 64' cherry rootstocks in Bosnia and Herzegovina. Acta Agriculturae Slovenica 99(2): 129-136. DOI: 10.2478/v10014-012-0012-5.

Erwin D.C., Ribeiro O.K. 1996. Phytophthora diseases worldwide. APS Press, American Phytopathological Society, St. Paul, MN, USA. pp. 562.

Exadaktylou E., Thomidis T., Grout B., Zakynthinos G., Tsipouridis C. 2009. Methods to improve the rooting of hardwood cuttings of the 'Gisela 5' cherry rootstock. HortTechnology 19(2): 254-259.

Fenn L.B., Feagley S. 1999. Review of beneficial uses of calcium and ammonium salts for stimulating plant growth and metabolite translocation. Soil Science and Plant Analysis 30(19-20): 2627-2641. DOI: 10.1080/00103629909370401.

Fotopoulos S., Sotiropoulos T.E. 2005. In vitro propagation of the PR 204/84 (Prunus persica $\times$ P. amygdalus) rootstock: Axillary shoot production and rhizogenesis. New Zealand Journal of Crop and Horticultural Science 33(1): 75-79. DOI: 10.1080/01140671.2005.9514333.

Glass A.D.M., Britto D.T., Kaiser B.N., Kinghorn J.R., Kronzucker H.J., Kumar A., et al. 2002. The regulation of nitrate and ammonium transport systems in plants. Journal of Experimental Botany 53(370):855-864. DOI: 10.1093/jexbot/53.370.855.
Hirschi K.D. 2004. The calcium conundrum. Both versatile nutrient and specific signal. Plant Physiology 136(1): 2438-2442. DOI: 10.1104/pp.104.046490.

Lambardi M., Roncasaglia R., Previati A., De Carlo A., Dradi G., Da Re F., Calamai L. 2006. In vitro slow growth storage of fruit rootstocks inside gas-tight or gas-permeable containers. Acta Horticulturae 725: 483-488. DOI: 10.17660/ActaHortic.2006.725.69.

Lloyd G., McCown B. 1980. Commercially-feasible micropropagation of mountain laurel, Kalmia latifolia by use shoot-tip culture. International Plant Propagators' Society 30: 421-427.

Long L.E. 2003. Cherry training systems, selection and development. PNW 543, Corvallis, Oregon State University.

Long L.E., Kaiser C. 2010. Sweet cherry rootstocks for the Pacific Northwest. A Pacific Northwest Extension Publication, PNW 619, Oregon State University.

Mansseri-Lamrioui A., Louerguioui A., Bonaly J., Yakoub-Bougdal S., Allili N., Gana-Kebbouche S. 2011. Proliferation and rooting of wild cherry: The influence of cytokinin and auxin types and their concentration. African Journal of Biotechnology 10(43): 8613-8624. DOI: 10.5897/AJB11.450.

Murashige T., Skoog F. 1962. A revised medium for rapid growth and bioassays with tobacco tissue culture. Physiologia Plantarum 15(3): 473-497.

Nacheva L., Gercheva P. 2009. Micropropagation of 'Gisela 5' (cherry dwarf rootstock): The effect of the type and the concentration of the carbohydrates in the nutrient medium. Acta Horticulturae 825: 261-267. DOI: 10.17660/ActaHortic.2009.825.41.

Pierik R.L.M. 1997. In vitro culture of higher plants. Springer Science and Business Media, Springer, Dordrecht, the Netherlands. DOI: 10.1007/978-94011-5750-6.

Quoirin M., Lepoivre P. 1977. Edude de milieu adaptes aux cultures in vitro de prunus. Acta Horticulturae 78: 437-442 (in French).

Reddy A.S.N. 2001. Calcium: Silver bullet in signaling. Plant Science 160(3): 381-404. DOI: 10.1016/S0168-9452(00)00386-1.

Ružić D., Sarić M., Cerović R., Ćulafić L. 2000. Relationship between the concentration of macroelements, their uptake and multiplication of cherry rootstock 'Gisela 5' in vitro. Plant Cell, 
Tissue and Organ Culture 63(1): 9-14. DOI: 10.1023/A:1006412901992.

Ružić D.V., Vujović T.I. 2008. The effects of cytokinin types and their concentration on in vitro multiplication of sweet cherry cv. 'Lapins' (Prunus avium L.). HortScience. 35: 12-21.

Sarropoulou V., Dimassi-Theriou K., Therios I. 2013. In vitro rooting and biochemical parameters in the cherry rootstocks CAB-6P and 'Gisela 6' using L-methionine. Turkish Journal of Agriculture and Forestry 37(6): 688-698. DOI: 10.3906/tar-1212-81. Šiško M. 2011. In vitro propagation of 'Gisela 5' (Prunus cerasus $\times$ P. canescens). Agricultura 8(1): 31-34.

Zimmermann A. 1994. 'Gisela 5', a dwarfing rootstock for sweet cherries from Giessen in a trial. Obstbau (Germany) 19: 62-63. 